\title{
EKONOMI KEUANGAN ISLAM DALAM KONSEP AL-MASHLAHAH AL-MURSALAH
}

\author{
Sudirman Suparmin \\ Universitas Islam Negeri Sumatera Utara \\ Email.sudirman.suparmin@uinsu.ac.id
}

\begin{abstract}
Economic activity has existed since the time of the Prophet Muhammad. The basic foundation has actually been made with his own practice as a trader in his youth, besides al-Quran and al-AlSunnah also mention the limits of economic activity. In line with the increasingly widespread development of Muslims, various economic model activities have also emerged, so that sometimes it is not uncommon to find activities that develop in society that were never carried out during the time of the Prophet Muhammad and in the text we also do not find in the Al-qur'an or al-Sunnah. But on the basis of human needs, these activities are justified on the basis of the method of al-Mashlahaht. This is because the law of Allah SWT always depends on the increase of His Supremacy. Basic economic methods al-ibahah (allowed) to do so long as there is no argument that prohibits it. What the companions of the Prophet (PBUH) did like Abu Bakr, Umar ibn Khattab was not uncommon based on al-Mashlahah.
\end{abstract}

Keywords: Islamic Financial Economics, al-Mashlahah al-Mursalah.

\begin{abstract}
Abstrak
Kegiatan ekonomi ada semenjak zaman Nabi Muhammad SAW. Pondasi dasar sesungguhnya telah dibuat dengan praktek beliau sendiri sebagai pedagang pada masa mudanya, disamping al-Quran dan al-Al-Sunnah juga menyebutkan batasan-batasan kegiatan ekonomi. Sejalan dengan perkembagan umat Islam yang semakin luas, berbagai kegiatan model ekonomi juga bermunculan, sehingga terkadang tidak jarang kita jumpai kegiatan-kegiatan yang berkembang di masyarakat tidak pernah dilakukan pada masa Rasulullah SAW dan secara teksnya juga tidak kita dapati dalam al-Quran maupun alSunnah. Namun atas dasar kebutuhan manusia maka kegiatan tesebut dibenarkan dengan landasan kaedah al-Mashlahaht. Hal ini karena hukum Allah SWT selalu bergantung dengan keMashlahahtan hambahNya. Dasar kaedah ekonomi al-ibahah (boleh) untuk melakukannya sepanjang tidak ada dalil yang melarangnya. Apa yang dilakukan sahabat Nabi SAW seperti Abu Bakar, Umar ibn Khattab tidak jarang berdasarkan al-Mashlahah.
\end{abstract}

Kata Kunci: Ekonomi Keuangan Islam, al-Mashlahah al-Mursalah. 
56 | TAZKIR: Jurnal Penelitian Ilmu-ilmu Sosial dan Keislaman

Vol. 06 No. 1 Juni 2020

\section{PENDAHULUAN}

Sesungguhnya Allah SWT sangat menyayangi manusia. Ia tidak menciptakan manusia dalam keadaan sia-sia, akan tetapi Ia jadikan manusia mempunyai tujuan dan tidak dibiarkan begitu saja tanpa diberi petunjuk jalan dan 'rambu-rambu' ilmu pengetahuan. Syari' at Islam menjadi panduan bagi manusia mengharungi kehidupan ini. Di dalamnya terkandung banyak hukum, dan hukum-hukum tersebut memastikan keMashlahahtan bagi keberlangsungan agama mereka dan kehidupan duniawi serta kehidupan ukhrawi.

Ulama menetapkan bahwa siapa yang mengamalkan hukum-hukum syari'at dan memperhatikan bahwasanya hukum syari'ah itu bertujuan untuk menetapkan keMashlahahtan yang lima macam dan menjaganya, yaitu agama, jiwa, akal, keturunan dan harta benda. Kesemua itu bertujuan untuk mencukupi keMashlahahtan tiga macam tahapan:

Pertama, hal-hal yang merupakan keharusan (dharurat), ialah keMashlahahtan yang harus dan paling utama dipenuhi untuk menegakkan dan menjaga keMashlahahtan yang lima.

Kedua, kebutuhan pokok (hajiyat), ialah apabila tidak dapat terpenuhi untuk menegakkan keMashlahahtan yang lima, paling tidak dapat mengurangi kesempitan dan kerugian saat menggunakannya.

Ketiga, perbaikan (tahsinat), ialah yang tidak harus terpenuhi untuk menegakkan kemaslahatan tersebut, dan tidak pula menolak kesempitan dan kerugian saat menggunakannya, akan tetapi untuk memenuhi kebutuhan tambahan dan merealisasikan akhlak yg baik. Kesemua Mashlahaht yang lima ini dapat menyempurnakan kebutuhan dharurat dan hajiyat sebagaimana tiap tingkatan dapat saling menutupi antara satu dengan yang lainnya.(al-Ghozali, 1993, hlm. 283) (al-Buthi, 1965, hlm. 78)

KeMashlahahtan pertama ialah agama yang terdapat pada tingkat yang paling tinggi, disebut juga dengan "dharuriyat". KeMashlahahtan agama ini diawali dengan kalimat syahadat, yaitu "Syahadatun an la Illaha Illa Allah Muhammad Rasulullah".(Azwar, 2015) Kalimat ini harus ditegakkan karena bertujuan menegakkan agama Allah. Walaupun dalam melakukannya mesti mengorbankan jiwa, seperti ikut dalam peperangan atau jihad membela kalimat Allah dan meneguhkan agama-Nya.

Keashlahahtan kedua disebut "hajiyat". Ia dapat menyempurnakan tegaknya agama yang sudah disyari'atkan Allah dari kemudahan dalam hukum 
untuk menghilangkan kesulitan dan kesusahan serta mencegah dari rasa sulit, seperti melakukan shalat dengan cara duduk bagi yang sudah uzur (sudah tua atau yang tidak sanggup berdiri), dan mengqashar (memendekkan) shalat bagi orang yang sedang dalam perjalanan jauh, juga akad jual beli dalam hukum mu'amalat.

KeMashlahahtan ketiga disebut "tahsiniyat". Ia dapat menyempurnakan tegaknya agama yang seharusnya dilakukan oleh seorang Muslim, seperti sifat pemaaf, tegur sapa yang santun, mengedepankan kebaikan dan meninggalkan keburukan.

Mashlahah berdiri di balik hukum yang diturunkan oleh Allah SWT. Ia menyuruh agar kita melihatnya selagi memiliki kemampuan. Jika tidak dapat melihatnya, maka iman seorang Muslim dan keyakinannya yang dapat mengakuinya. Allah tidak akan memaksa untuk itu melainkan memudahkannya, dan tidak pula disyaria'tkan baginya melainkan untuk kebenaran dan kebaikan. Semua itu sudah lengkap karena kita memperoleh apa yang sudah dikaji oleh para ulama, dimana setiap hukum syari'at terdapat sebuah mashalahah. Satu kaedah menyebutkan: Di balik hukum ada mashalahah, seyogyanya terikat dengan beberapa syarat dan batasan yang kami tunjukkan kepadanya, dan jika tidak ada, maka hukum itu tidak dapat dibangun atas dasar sebuah keMashlahahtan bagi manusia".(Abdussalam, t.t., hlm. 4)

\section{METODE PEMBAHASAN}

Pendekatan yang digunakan dalam artikel ini adalah pendekatan kualitatif. Penelitian kualitatif sebagai prosedur penelitian yang menghasilkan data deskriptif berupa kata-kata tertulis atau lisan dari orang- orang atau perilaku yang dapat diamati.(Moeleong, 2006)

Penelitian yang menghasilkan data deskriptif maksudnya adalah metode penelitian yang digunakan untuk menggambarkan semua data atau keadaan subjek atau objek penelitian kemudian dianalisis dan dibandingkan berdasarkan kenyataan yang sedang berlangsung pada saat ini dan selanjutnya mencoba untuk memberikan pemecahan masalahnya dan dapat memberikan informasi yang mutakhir sehingga bermanfaat bagi perkembangan ilmu pengetahuan serta lebih banyak dapat diterapkan pada berbagai masalah. Penelitian deskriptif secara garis besar merupakan kegiatan penelitian yang hendak membuat 
58 | TAZKIR: Jurnal Penelitian Ilmu-ilmu Sosial dan Keislaman

Vol. 06 No. 1 Juni 2020

gambaran atau mencoba melihat suatu peristiwa atau gejala secara sistematis, faktual dengan penyusunan yang akurat.(Supardi, 2005, hlm. 28)

\section{HASIL DAN PEMBAHASAN}

\section{Mashlahah dalam Perspektif Syari'ah}

Mashlahah sama seperti "manfa'ah" baik secara timbangan kata maupun makna. Ia adalah bentuk kata dasar yang berarti kebaikan seperti bentuk kata benda yang menunjukkan satu dari Mashlahah, bentuk kata kerja perintah ialah Mashlahah yaitu baik.

Manfa'ah (manfaat) ialah sesuatu yang menghasilkan kelezatan dan bersifat kekal. Maksud dengan kelezatan dapat memperolehnya dan maksud kekal adalah tetap terjaga atasnya.

Mashlahah dalam pandangan Ulama Ushuliyah: Imam al-Ghazali mengatakan; Mashlahah adalah dasar atau asas dari mendatangkan mashlahah atau menolak mafsadah. Sesungguhnya mendatangkan mashlahah dan menolak mudhratan adalah tujuan dari penciptaan. Oleh karena itu, al-mashlahah adalah menjaga tujuan syari'at dan tujuan penciptaan yang lima, yaitu mereka menjaga agamanya, jiwa, akal, keturunan dan harta benda. Seluruh yang termasuk menjaga konsepsi yang lima ini disebut mashlahah (kemashlahatan), seluruh yang menghilangkan konsepsi yang lima pula disebut mafsadah (kerusakan), menolaknya termasuk mashlahah. Ukuran mashlahah adalah sesuainya antara tujuan syari' dengan menjaga mashalahah umum yang lima.(al-Ghozali, 1993, hlm. 286)

Imam 'Izuddin berkata, al-mashlahah ada dua macam : Pertama, Mashlahah Hakiki, yaitu kegembiraan dan kesenangan, kedua; Mashlahah Majazi, yaitu; sebab-sebanya. Terkadang sebab-sebab mashlahah dan mafsadah yang diperintahkan atau dibolehkan bukan karena keadaannya rusak, tetapi karena keadaannya membawa kemashlahatan, seperti potong tangan orang yang melakukan korupsi. Hal itu dilakukan karena menjaga nyawa. Bertaruhan nyawa dalam peperangan karena menjaga agama Allah SWT, dan semua jenis sanksi-sanksi syari'ah bukan itu yang dicari karena keadaan merusak, tetapi karena tujuan syari'ah, seperti potong tangan pencuri dan perampokan di jalan, pembunuh janin, rajam pezinah perempuan, cambuk dan pengasingan bagi penzina. Itu semua namanya sebagai $t a^{\prime} z i r a t$ (hukuman yang memberi pelajaran). Semua bentuk kemafsadatan dalam syari'at mewajibkan agar mendatangkan 
sebuah kemashlahatan hakikiyah. Mashlahah seperti ini disebut mashlahah majazi, dengan istilah menggunakan nama sebab dengan tujuan musabbab.

Imam Syatiby mengatakan bahwa maksud dari mashalih adalah sesuatu yang kembali kepada berlangsungnya hidup manusia dan sejahtera hidupnya, dapat memenuhi apa yang ia kehendaki atau terlepas dari keinginan syahwat dan akal secara mutlak. Pada dasarnya, hal tersebut merupakan sesuatu yang sulit terjadi, karena mashalih itu sedikit banyaknya tidak terlepas dari beban dan kesulitan, seperti makan, minum, pakaian, tempat tinggal, kendaraan, perkawinan dan lain sebagainya. Semua perkara ini tidak bisa dicapai kecuali dengan rasa lelah. Sebagaimana pula pada mafasid duniawiyah, bukan sematamata kerusakan dari segi situasi yang ada, tidaklah mafsadah itu terjadi pada kebiasaan yang berlaku melainkan ada hubungan dengannya, baik yang mendahului maupun mengikutinya dari sifat lemah lembut dan kenikmatankenikmatan.(Asy-Syatibi, 1997, hlm. 25-26)

\section{Pondasi Dasar Mashlahah Menurut Jumhur Ulama Ushuly}

Mashlahah al-Mursalah di bentuk di atas pondasi, dengan memiliki beberapa ketentuan dasar, yaitu;

1. Mashlahah Tidak berbenturan dengan nash dan kesepakatan ulama (ijmak), jika berbenturan maka mashlah tidak berlaku, karna dasar pembentukan alMashlahah tidak ada dalil yang melarang dan juga perintah.

2. Merealisasikan salah satu Mashlahah yang lima; agama, jiwa, akal, keturunan dan harta, yakni Mashlahah harus sesuai dengan Mashlahah yang lima.

3. Mashlahah itu haqiqiyah dan umum. Jika tidak haqiqiyah akan menjadi kebimbangan, kebimbangan tidak dapat dibentuk atasnya hukum syariat, dan jika bentuk umum, bentuk khusus, hukum-hukum dalam syariat Islam tidak dibuat untuk individu dan tidak untuk sekelompok orang, akan tetapi untuk semua manusia tanpa melihat perbedaan.

Pondasi-pondasi ini pada hakikatnya berlandaskan dari sifat alami Mashlahaht dan dari dalil syar'i. Sebahagian ulama menambahkan beberapa pondasi yang lain diantaranya Imam Syafi'i. namun pondasi yang di utarakan oleh imam syafi'i pada dasarnya syarat pondasi yang kedua yaitu mengisyaratkan bahwa Mashlahah satu jenis yang sama dengan apa yang datang dari Allah SWT. 
60 | TAZKIR: Jurnal Penelitian Ilmu-ilmu Sosial dan Keislaman

Vol. 06 No. 1 Juni 2020

Al-Mashlahah dalam pandangan Imam al-Ghazali: Mashlahah adalah dharuriyat. terkadang sector perbuatan terbatas dengan Mashlahah al mursalah pada tingkat dharuriyat tidak pada semua tingkatan (al hajiyat dan al tahsiniyat), terkadang benar apabila kami batasi dari satu pengarang kitab (al mushtashfa), tapi dugaan ini terkadang tidak tepat bila kita kembali kepada kitab-kitab yang lainnya. Semoga apa yang di jelaskan kitab al mushtashfa di dalamnya ada titik persamaan antara semua ulama ushul, yaitu melakukan Mashlahaht dharuriyat bagi semua ulama fuqaha tanpa kecuali, bila kita rujuk kepada kaedah asal yaitu: Kondisi darurat membolehkan sesuatu yang dilarang. (Abdul Wahab al-Khalaf, alIjtihad bi ar-Ra'i. h. 94)

\section{Tolak Ukur Al-Mashalih Dalam Syariat Islam}

Ketahuilah bahwa tolak ukur al-mashalih dan al mafasid adalah dengan syari'ah bukan dengan kemauan sendiri (hawa nafsu). berkata syeikh Islam ibnu taimiyah ra, "Tolak ukur dalam menimbang al-mashalih dan al mafasid ialah timbangan syari'ah, bilamana manusia mengukurnya dengan mengikut nashnash yang belum dimodifikasi, jika tidak itu adalah hasil ijtihadnya sendiri.(Mhd Ali, 1411, hlm. 40)

Tingkat Pertama dapat kita melihat; adakah al mashalih dan al mafasid yang kita maksud telah datang dengan timbangan antara nash syari'ah atau tidak? Jika al Mashlahah dan mafasid sesuai dengan nash maka wajib mengikutinya. Sekiranya orang bertanya: Seorang yang tetap tinggal bersama orang tuanya demi berbakti kepada keduanya dan atau ia keluar dengan sukarela pergi berjihad meskipun tanpa izin kedua orang tua? Dua Mashlahaht tersebut mana yang didahlukan? Tolak ukurnya dan jawabannya terdapat dalam nash syari'ah dengan tidak meninggalkan kesempatan berjihad, dalam sebuah hadits ibnu Mas'ud ra, ia berkata; aku bertanya Rasulullah SAW: perbuatan apa yang lebih dicintai Allah? rasul menjawab: shalat tepat pada waktunya, aku Tanya lagi: kemudian apa? Beliau jawab "berbuat baik pada dua orang tua. Aku Tanya lagi: kemudia apa? Beliau jawab : berjihad di jalan Allah. (HR. al-Bukhari, Bab: fi alMawaqit, 2/9) Bila dibandingkan masalah ini tidak ada nash (dalil) jelas yang membawa kemungkinan terjadi kerusakan, atau luput dari Mashlahah, atau mendahului mashlalah dari pada yang lain, maka disini dapat dikatakan bahwa ini adalah hasil ijtihad ulama.(Mhd Ali, 1411, hlm. 40-41) 


\section{Hukum Allah SWT Berkaitan Dengan Kemashlahatan}

Sungguh banyak sekali dalil-dalil hukum syari'ah yang dibangun atas dasar Mashlahah bagi manusia yaitu untuk kemashalahah kehidupan dunia maupun akhirat.

Diantaranya Nash-nash yang menunjukkan atas penjelasan perbuatan Allah SWT dan hukumNya. Banyak kita jumpai dalam al quran dan al al-AlSunnah yang tidak dapat dihitung, contoh; firman Allah SWT tentang perintah shalat, zakat dan haji:

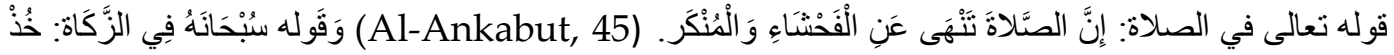

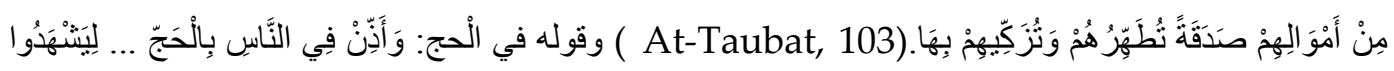

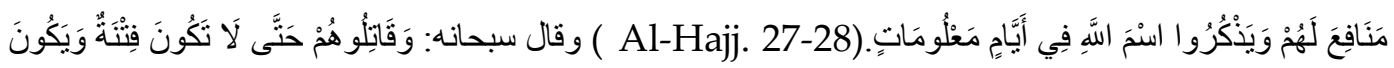

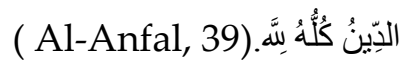

Dan hadis Nabi SAW:

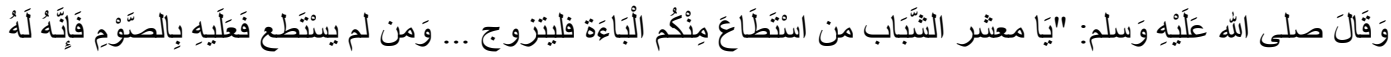

وَجَاء". (HR. al-Bukhari, jilid 9, h. 106)

Berkata Imam al Syatibi ra: "Pendapat yang terpecaya adalah, aku sudah menela'ah tentang hukum syari'ah bahwasanya diletakkan untuk keMashlahaht manusia, begitu juga dalam penjelasan Imam ar-Rajiy." (Asy-Syatibi, 1997, hlm. 6-7) Firman Allah SWT:

$$
\text { وَمَا أَرْنَلْنَالَكَ إِلَّ رَحْمَةِ لِلْعَالَمِينَ }
$$

Berkata al 'adhd al ijiy :"Makna zahir ayat ini adalah umum, yakni dapat dipahami untuk menjaga Mashlahah mereka apa yang sudah disyari'atkan bagi mereka semua hukum-hukumnya, jikalau diutus dengan hukum tidak ada mashalahat bagi manusia, niscaya hadirnya agama Allah SWT tidak mengandung rahmat, sesuatu beban tanpa faidah (manfaat), maka bertentangan dengan makna zahirnya ayat tersebut."(al-Maliki, 2012, hlm. 238)

Dari al-Al-Sunnah : bersabda Rasulullah SAW:

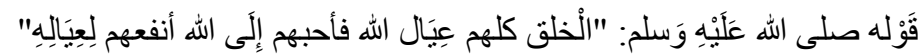

Makhluk (secara umum) adalah Hamba Allah SWT, maka mereka (para makhluk) yang paling dicintai oleh Allah SWT adalah yang memberikan manfaat kepada Hamba Allah SWT (yang lainnya). (HR. Thabrani wa Abu Ya'la, dan disebutkan as-Sakhowi: memiliki beberapa jalan dan tujuan yang baik. h. 200) 
62 | TAZKIR: Jurnal Penelitian Ilmu-ilmu Sosial dan Keislaman

Vol. 06 No. 1 Juni 2020

Rasul menjelasakan bahwa ruang dekatnya sesorang dengan Allah selama ia memberikan manfaa'at dan memberi bantuan kepada orang lain, mengawasi keMashlahahtan mereka dan memberikan bantuan yang dapat membahagiakan mereka.

Jika ukuran Mashlahah adalah apabila manusia mendekat kepada Allah SWT dengan amalnya: yaitu dengan membantu keMashlahahtan orang orang lain, maka ukuran ini sesungguhhnya adalah sebuah hukum dan sesuai dengan ketentuan hukum syara' itu sendiri.(Al-Buthi, 1973, hlm. 78-79)

\section{Al-Mashalih Al-Mursalah Dalam Konsep Ekonomi dan Keuangan}

\section{Cek atau Surat Berharga}

Pada masa sebelum datang ajaran agama Islam belum ada beredar cek uang, begitu pula pada masa Rasulullah, pada masa Abu Bakar dalam bentuk khusus, bahkan mereka saling tukar menukar uang rumaniyah dan farisiyah, Umar bin al Khattab ra, merasa terganngu dengan adanya uang tersebut karena takut bahwa itu palsu.

Pada suatu hari beliau berkata; aku berkeinginan untuk membuat uang dirham dari kulit unta, lalu orang mengatakan: kenapa tidak dari unta saja. Lalu ia memegang uang tersebut, saat beliau membeli sesuatu keperluan ia kalikan dengan uang dirham farisi, dan mempolesnya dengan bentuk lukisan corak

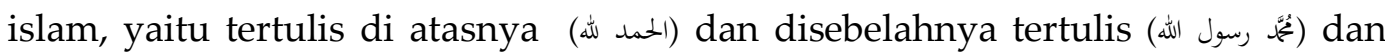
yang lain tertulis (لا إله إلا الله ). Pada akhir hayatnya beliau lakukan modifikasi atau pengukuran nilai pada timbangan, tiap sepuluh dirham enam kali berat biji atom. Akan tetapi Umar bin al khattab tidak menjadikan uang dinar sebagai nilai harga, abdul Malik bin Marwan yang menjadikan nilai uang dinar.(Al-Maqriziy, 1998, hlm. 59) (Al-Maqriziy, 1998, hlm. 827) (Fahmi, t.t., hlm. 177)

Apa yang telah dilakukan Umar bin al Khattab tidak pernah dilakukan pada masa Rasulullah SAW karena tidak dibutuhkan, tetapi dimulai dari kepemimpinnan Umar sehingga meluas dan terjadi percampuaran dengan jenis lain. Akhirnya cek uang tersebut dibutuhkan untuk keperluan tertentu diantaranya :

1. Pemalsuan dan penipuan yang membawa dirham dan dinar romawi dan farisi. 
2. Negara Islam menjadi Negara terpisah / independen kepemimpinna masingmasing Negara berbeda dalam menggunakan cek uang nya, berusaha untk memasukkan mata uang tertentu dalam persaingan global di berbagai pasar.

3. Inilah yang dilakukan oleh Umar bin al Kkhattab walaupun apa yang dilakukan nya tidak ada dalam nash secara khusus, akan tetapi sejalan dengan tujuan Syari', karena ia termasuk ke dalam perkara tahsiniyat yang menunjukkan kekhassan suatu Negara, jika tidak kita lakukan, sesungguhnya bisa saja terkadang sampai kepada tingkat keperluan pokok (hajiyah). di sini seharusnya kita bersikap untuk menjadikan sebagai pembelajaran dan ibrah dari gagasan yang dilakukan Umar bin al Khattab.

Islamnya Umar bin al Khattab tidak ada satupun yang dapat menghalanginya mengikut system keuangan yang ada pada umat selain islam melihat konsekwensi kondisis kehidupan masyarakat secara umum, tetapi boleh mengikut pada setiap sesuatu yang dapat menguntungkannya.

Seharusnya ummat Islam tetap selamanya berbeda pada esensinya dan bahagian rincinya jika terkait dengan urusan aqidah dan ibadah. Dan berbeda pada esnsinya tapi tidak pada bahagian rincinya atau furu'iyah jika terkait dengan perkara 'Adah (bukan aqidah dan ibadah) dan muamalah. Dan apa yang dilakukan Umar meniru (afiliasi) bangsa Romawe dan farsia dalam masalah keuangan, tapi berbeda pada lambang yang diletakkan pada mata uang tersebut. Muslimin hari ini mereka banyak yang meniru apa yang datang dari bangsa non muslim . contoh

1. Negara Arab mengikut system pertahanan Negara timur saat mendatangkan peraturan baris berbaris pada tentera dan polisi yaitu; ketika mulai melangkah untuk maju jalan dimulai dengan kaki kiri .

2. Pertarungan gulat dari jepang, saat masuk pada penghitungan jumlah, kita ikuti cara itu dengan esensi dan bahagian rincinya bahkan meyakininya, yaitu membungkukkan badan, memberikan salam dari tradisi mereka.

\section{Penggolongan Gaji dan Pemberian Bonus Pegawai Negeri}

Pada masa rasul para pekerja dan pegawai tidak ada diterapkan pembayaran gaji secara khusus, dan tidak pula pada kepemimpinan Abu Bakar, tapi mereka dibayar gaji nya menurut siatuai dan kondisi mereka. Pada masa kepemimpinan Umar bin al khattab barulah ada pembayaran gaji pegawai secara khusus. 
64 | TAZKIR: Jurnal Penelitian Ilmu-ilmu Sosial dan Keislaman

Vol. 06 No. 1 Juni 2020

Adakalahnya pembayaran gajih pertahun, seperti gaji Mua'wiyah ke negeri Syam, dibayar sebanyak 1000 dinar tiap tahun. Dan adakalahnya pembayaran gaji setiap bulan seperti gaji Umar bin Yasir ke negeri Kufah, dibayar sebanyak 600 dirham tiap bulan. Abdullah bin Mas'ud menjabat sebagai hakim di Kufah gaji nya dibayar sebanyak 100 dirham ditambah bonus harian senilai seperempat ekor kambing. 'Iyadh bin Ghanam ke negeri Hams gajinya dibayar harian senilai satu ekor kambing dan satu mud makanan

Umar bin al-khattab memberikan perhatian yang cukup serius khususnya pada pembayaran gaji para hakim, beliau bayar dengan rasa murah ahti, supaya mereka mendapat tempat yang terhormat, dan merekapun tidak berpikir untuk melakukan praktik makan uang suap dan gratifikasi. Umar bin al Khattab menyampaikan kepada Mu'az bin Jabal, Abu ubaidah dalam bentuk tulisan saat beliau mengutus mereka ke negeri Syam berbunyi: "ikutilah kebaikan orang-orang sebelum kalian, mereka benar-benar bekerja sebagai hakim, dan memberikan kesempatan atas warga mereka, dan member sebagian dari rezekinya, dan merasa cukup dengan apa yang mereka miliki".

Inilah corak politik Umar ra, yang besifat lapang dada tarhadap pegawai negeri dari kalangan muslimin, apalagi mereka menjabat sebagai hakim, berbeda dengan apa yang dipahami oleh sebagian orang bahwa kaum muslimin itu berprilaku keras.

Penetapan gaji yang dilakukan Umar ibn Khattab, system ini tidak ada terdapat pada masa rasullullah karena belum dibutuhkan, karena tugas pekerjaan sedikit pada masanya, apalagi maslah urusan politik, ini sejalan dengan tujuan Syari' terhadap kepemimpinan Umar bin al Khattab karena masalah tersebut sudah sangat dibutuhkan.

\section{Pelatihan Skill dan Kerajinan Tangan}

Umar bin al Khattab melihat bahwa jenis pekerjaan ini penting supaya harta tetap beredar di tangan orang-orang Islam tertentu, karena mereka akan mengeluarkan infaq bila mereka diajak. Dan juga kesibukan orang islam dalam tiap-tiap pekerjaan dan kerajinan, lebih-lebih lagi kegiatan yang mereka tekuni dibidangnya sehingga tidak diambil alih oleh orang lain dan tidak menguasai pasar sehingga mereka dengan mudah dan sesuka hatinya menaikan harga barang.

Riwayat Abu 'Addi berkata: kami duduk di dalam masjid lalu umar bin al khattab berdiri, kami bertanya: kemana kamu pergi wahai Umar? Beliau menjwab: Aku mau pergi ke pasar untuk melihat. Lalu ia mengambil susunya 
dan pergi , kami pun duduk memperhatikan beliau, tatkala beliau pulang kami bertanya; bagaimana kamu lihat pasar wahai amirul mukminin? Beliau menjawab: aku melihat seorang budak dan tuannya keluarga yang bahagia, orang arab didalamnya hanya sedikit. Kamu bertanya lagi : wahai amirul mukminin sesungguhhnya kami dikayakan allah dengan harta rampasan, kami tidak suka kehinaan, cukup lah tuan-tuan kami dan anak anak kami. Ia berkata : demi Allah jika kamu meninggalkan mereka, laki-laki kalian memerlukan lakilaki mereka, perempuan kalian memerlukan perempuan mereka.( Ibnu Syabah, Jilid 2, hlm, 747)

Semua gagasan ini Umar telah menjadikannaya untuk mendorong orang muslimin. ia berkata: kalian pelajarilah suatu keterampilan,...,dan ia berkata; jikalau tidk ada jual beli niscara kamu meminta -minta sama manusia. Dan Umar saat itu kagum kepada seorang anak kecil ia bertanya kepadanya ; apakah ia punya pekerjaan? Orang menjawab : tidak, jatuh air matanya. (Nizhom alHukumah al-Nabawi, Syekh Abdul Al-Hay al-Katani. Jilid 2, hlm. 22-23)

Pada saat kepemimpinan umar telah berkembang kegiatan dagang, dan banyak jenis keterampilan, sebahagian kaum muslimin banyak yang tidak berjualan di pasar karena banyak barang impor dari luar, walaupun orang lain sanggup menguasai sebahagian pekerjaan dan hasil industry. Umar mendorong kaum muslimin untuk masuk ke pasar dan bersaing dengan orang lain sebelum datang masa yang mana kaum laki-laki mereka membantu laki-laki lain, dan perempuan membantu perempuan lain.

Apa yang dilakukan Umar sejalan dengan keMashlahahtan dan sejalan dengan kandungan nash yaitu bahwa pemipin itu harus dari kalangan muslumin. Firman Allah dalam surah al Nisa' ayat:141

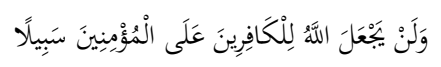

dan Allah sekali-kali tidak akan memberi jalan kepada orang-orang kafir untuk memusnahkan orang-orang yang beriman. Dan firman Allah SWT dalam surat Ali Imran, ayat 28:

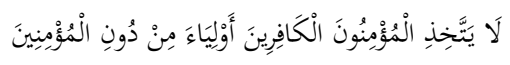

Janganlah orang-orang mukmin mengambil orang-orang kafir menjadi wali[192] dengan meninggalkan orang-orang mukmin.

\section{Pengutipan Pajak}


66 | TAZKIR: Jurnal Penelitian Ilmu-ilmu Sosial dan Keislaman

Vol. 06 No. 1 Juni 2020

Yaitu sejumlah uang yang dipungut dari peperangan dan dari pelanggaran undang-undang dari orang yang sudah mukallaf disebut sepersepuluh. Pungutan pajak tidak ada pada masa rasul dan Abu bakar.

Setelah meluas area dan terjalin hubungan dagang antara kaum muslimin dan kaum kafir harbi, Abu musa menulis sebauh surat kepada Umar berbunyi :sesungguhhnya pedagang muslimin bila mereka masuk ke wilayah perang mereka dipungut dari kaum kafir seperpuluh dari harta mereka. Lalu Umar membalas surat itu : "ambillah harta mereka jika mereka masuk ke wilayah kita", ambillah dari pedagang mereka sepersepuluh dari hartanya. Tidak dipungut pajak bagi siapa yang memilki harta kurang dari 200 Dirham. Begitu pula dapat diambil satu kali pada tiap tahun, kecuali kafir harbi sesunguhnya harta mereka diambil setiap mereka masuk ke wilayah kita.

Apa yang dikerjakan Umar bin al Khattab ra, tidak dinyatakan dengan nash khusus, tapi sejalan dengan tujuan syari'ah keMashlahahtan, karena ia terkandung di bawah undang-undang mua'malah.

\section{PENUTUP}

Ciptaan Allah SWT keseluruhan penuh degan hikmah,dan dibangun atas realisasi tujuan syari'ah dan keMashlahahtan kembali kepada makhluq ciptaanNya. Tujuan dan kemaslahatan berfokus pada memperoleh kebaikan atau menolak kemudratan yang dialami makhluq. Syari'ah berlaku untuk merealisasikan kemaslahatan manusia di dunia dan di akhirat, bukan berlaku sebagai ibadah hukum halal dan haram tanpa ada tujuan tertentu di balik perintahnya, larangannya, dan bolehnya, bahkan hukum-humkumnya secara keseluruhan disebabkan dengan hukum dan Mashlahaht menurut mayoritas ulama. Semua itu berdalilkan atas al quran, al al-Sunnah, ijmak dan prilaku shabat.

Sesungguhhnya Mashlahah itu terkadang mempunyai nash dalam ayat al quran, dan terkadang tidak mempunyai nash, akan tetapi orang mempunyai ilmu menjadikan petunjuk dengan ilmu Allah, dan dengan pemahaman yang datang dari al quran dan al al-Al-Sunnah lalu ia ambil kesimpulan hukumnya, dalam maslah ini harus menjaga kaedah ta'lil, standarnya, metodologinya, dan batasannya sehingga tidak menjadi rusak dengan seleranya hawa nafsunya, dan bagi orang yang faqih harus pula bangun dan melek, dan pandangan tajam dan menela'ah secara sempurna apa yang ia senggup mengambil kesimpulan hukum illat yang benar dan hikmah tujuan dan hukum tersebut. WAllahu a'lam bi al shawab. 


\section{DAFTAR PUSTAKA}

Abdussalam, I. ad-D. I. (t.t.). Qawaid al-Ahkam fi Masholih al-Anam (1990 ed.). Dar al-Ma'arif.

Abdul Wahab al-Khalaf, Al-Ijtihad bi ar-Ra'i,

Abu Ubaid. (1986). Al-Amwal, Tahqiq: Muhammad Kholil Haras, Dar al-Kutub alAlamiyah, Lubnan, at-Ba'ah al-Ula.

al-Buthi, Dr. M. S. (1965). Risalah. Muassasah ar-Risalah.

al-Ghozali, A. H. (1993). Al-Mushtashfa. Dar al-Kutub al-Alamiyah.

al-Maliki, K. ibn I. al-Jundi. (2012). Syarh Mukhtashar Ibn Hajib. Dar Ibn Hazim.

Al-Buthi, M. S. R. (1973). Dhowabit al-Mashlahah fi Syari'ah al-Islamiyah. Muassasah ar-Risalah.

Al-Maqriziy. (1998). An-Nuqud al-Islamiyah. Dar al-Hadis.

Al-Qol'azi. (1986).Mausu'ah figh Umar bin al-Khotab, Dar an-Nafais, Baerut, Jilid ke 3.

Al-Quran, Kemenag, RI

Asy-Syatibi. (1997). Al-Muwaffaqat Fi Ushul as-Syari'ah. Dar Ibn Affan.

Azwar, Z. (2015). Pemikiran Ushul Fikih Al-Ghazâlî Tentang Al-Maslahah AlMursalah (Studi Eksplorasi terhadap Kitab al-Mustashfâ min 'Ilmi alUshûl Karya Al-Ghazâlî). FITRAH:Jurnal Kajian Ilmu-ilmu Keislaman, 1(1), 47-70. https://doi.org/10.24952/fitrah.v1i1.327

Fahmi, M. A. M. (t.t.). Umar bin al-Khotob Qodiyan wa Mujtahidan.

Ibnu Syaibah, Tarikh al-Madinah al-Munawarah, Tahqiq: Fahim muhammad saltut, Taba'ah as-Saniyah.

Jamil A. K. (2003). Hundred Gread Muslims. Terjemahan Tim Penerjemah Pustaka Firdaus

Kamaruddin, Rusli, Politics in The Works of al Ghazali, Jurnal Intellectual Discourse UKM Malaysia, Volume 12 No. 2 tahun 2004 
68 | TAZKIR: Jurnal Penelitian Ilmu-ilmu Sosial dan Keislaman Vol. 06 No. 1 Juni 2020

Mhd Ali, A. A. H. A. al-Qadir. (1411). Al-Adillah ala 'Itibar al-Mashalih wa alMafasid fi al-Fatawa wa al-Ahkam. Dar as-Shofwa, al-Qohirah.

Moeleong, L. J. (2006). Metodologi Penelitian Kualitatif. PT Remaja Rosdakarya.

Muhammad Isa, S. T. (2016). Pengelolaan Sumber Daya Insani Dalam Memasarkan Produk Dan Jasa Lembaga Keuangan Syariah. FITRAH:Jurnal Kajian Ilmu-Ilmu Keislaman, 2(2), 17-36. https://doi.org/10.24952/fitrah.v2i2.469

Musthafa al-Bigho, Shohih al-Bukhori, Matba'ah al-Hindi.

Nofinawati, N. (2016). Analisis Terhadap Aplikasi Akad Murabahah Di Bank Syariah. At-tijaroh: Jurnal Ilmu Manajemen dan Bisnis Islam, 2(1), 98-111. https://doi.org/10.24952/tijaroh.v2i1.790

Supardi. (2005). Metodologi Penelitian Ekonomi Dan Bisnis. UII Press. 